\title{
Problem-Based Geometry in Seventh Grade: Examining the Effect of Path-Based Vs. Conventional Instruction on Learning Outcomes
}

\author{
https://doi.org/10.3991/ijet.v16i12.21349 \\ Andreja Klančar ( $₫)$ \\ University of Primorska, Koper, Slovenia \\ Hero Janez Hribar Elementary School, Stari trg pri Ložu, Slovenia \\ andreja.klancar@pef.upr.si \\ Andreja Istenič Starčič \\ University of Primorska, Koper, Slovenia \\ University of Ljubljana, Ljubljana, Slovenia \\ Federal University of Kazan, Kazan, Russia \\ Mara Cotič, Amalija Žakelj \\ University of Primorska, Koper, Slovenia
}

\begin{abstract}
This experimental study examined the impact of learning and teaching geometry in seventh-grade geometry education comparing learningpath and conventional instruction. According to constructivism, a learning path with the use of learning objects should enhance learner autonomy and selfdirectedness by providing differentiated instruction. We designed a model of path-based geometry learning in a learning management system-based learning environment with the use of dynamic geometry programs and applets, which fosters visualisation and the exploration of geometric concepts through the manipulation of interactive virtual representations. The results show that the experimental group (EG) achieved higher scores on all levels of knowledge and statistically significantly better results in taxonomy level-III tasks (problemsolving knowledge) and overall score than the control group (CG). There was initial equivalence between the EG and CG in prior knowledge. The authors concluded that path-based geometry learning empirically develops knowledge at higher cognitive levels.
\end{abstract}

Keywords - Mathematical education, geometry, path-based learning, learningmanagement system, interactive learning environments, dynamic geometry programs, applets

\section{Introduction}

The fundamental role of teaching mathematics is to develop mathematical competence and thus the ability to use mathematics in everyday life. Various national and international surveys systematically monitor and measure students' knowledge at different school levels and in different areas. 
The OECD's Programme for International Student Assessment (PISA) survey measures the abilities of 15-year-olds to use their knowledge and skills in reading, mathematics and science to meet the challenges of real life. The basic skills in these areas enable students to successfully continue their education and integration into society and thus to be successful and efficient in everyday life. In 2012, the PISA survey focused on mathematical literacy. The results showed that the performance in mathematical literacy in Slovenia has been stable in recent years. In Slovenia, $80 \%$ of students attained at least Level 2 proficiency in mathematical literacy (OECD average: $78 \%$; EU average: $77 \%$ ) [21].

Slovenian students are also involved in the National Assessment of Knowledge, which is carried out by the National Examinations Centre and the National Education Institute. In the nine-year primary education programme, education is divided into three 3-year periods, at the end of which the students' knowledge is assessed by the National Assessment of Knowledge.

An analysis of the mathematical performance of students in the school years 2010/11 to 2014/15 [13], [14], [15], [16], [17] shows that the weaker academic areas often included geometry (except the 2010/11 school year, in which ninth-graders successfully solved geometric problem-solving tasks, which usually requires complex procedures and problem-solving knowledge), measurement and, in 2013/14 and 2014/15, problem-solving, especially complex problems from everyday life.

In the field of geometry, sixth-graders were weaker in their understanding and knowledge of basic geometric concepts, and ninth-graders were weaker in the field of spatial representation, which manifests itself both in plane geometry and in the solution of complex problems in spatial geometry [13], [14], [15], [16], [17]. The ability of spatial representation is crucial to understanding geometry. It plays an essential role in mathematical thinking and influences success, not only in geometry, but in all mathematical disciplines. Visualisation plays an important role in the development of spatial representations of geometric concepts [28]. By improving the ability to visualise, we can improve the ability to spatially represent shapes and think abstractly and logically, which is crucial for solving everyday problems. With an appropriate teaching approach and appropriate teaching and learning strategies, the teacher can help students develop spatial representations [11].

\section{Higher-Order Learning Outcomes and Path-Based Learning Using LMS}

The development of learning resources available on the Internet assists individualised, differentiated instruction. For its effective, efficient integration in teaching and learning, many researchers have explored the path-based approach [2], [5], [19], [22], [25]. A learning path is a learning-environment functionality that integrates learning objects in a road map for students [4] and is aimed at a student's individual inquiry in learning to select their learning activities [22]. The new concepts in learning design, such as learning objects, appeared with the development of constructivism and the Internet in the 1990s [24]. Learning objects are self-standing digital instructional components available on the Internet that can be reused in a diverse learning environment [24]. According to constructivism, a learning path with the use of learning 
objects enhances learner autonomy and self-directedness by providing differentiated instruction. The learner must make decisions in their learning process about the inquiry and use of available learning resources.

Researchers have examined the effects of path-based methods on the learning outcomes of students in comparison to conventional instruction and studied learningmanagement system (LMS)-based learning environments [5].

Integrating technology into path-based geometry lessons, especially with the use of dynamic geometry programs and applets, fosters (1) visualisation and (2) the exploration of mathematical concepts through the manipulation of interactive virtual representations [10]. It helps students visualise and so facilitates the comprehension of geometric concepts. Computer-based graphical representations of geometric concepts are more representative than paper-based representations. The clarity of interactive displays facilitates observing and grasping concepts and conjectures, thus enabling a more fluent transition between different representations, especially between the visual and abstract levels [1].

For the purpose of the pedagogical experiment, we designed a model of path-based geometry learning in an LMS-based learning environment considering the guidelines of national [6], [7], [14], [15], [16], [17] and foreign literature [2], [5], [19], [22] to address the challenges of teaching geometry in Slovenian education [7], [20], [21].

In path-based learning, students transition between geometric reasoning with problem visualisation, problem analysis and forecasting solutions. Our model of pathbased geometry learning integrates the principles of individualisation and differentiation, meaning that students select their own paths and applications of learning objects according to their prior knowledge and preferences.

Recommendations concerning the use of information and communications technology (ICT) in mathematics education vary from country to country in Europe. In Slovenia, the use of ICT in mathematics education is included in the pedagogical recommendations of the curriculum. Some contents provide for the use of ICT, while others recommend using ICT only and leave the decision, whether to include ICT into math lessons or not, to the teacher.

All these facts prompted us to study the impact of path-based geometry learning in an LMS-based learning environment with the use of dynamic geometry programs and applets to facilitate learner-centred instruction.

\section{Description of The Model}

We designed and evaluated a model of path-based learning of seventh-grade geometry in an LMS-based learning environment with the use of dynamic geometry programs and applets. The learning path was designed in the LMS by applying a range of learning objects. Individualised learning in the model of path-based geometry learning was guided by a teacher and supported by guidelines. Students developed knowledge through research. The path-based approach facilitates self-directedness and the autonomous selection of learning objects, and the transition between the stages of geometric reasoning is contingent on individual students and their selection of learning objects. 
As an example, we present learning path for researching the area of trapezoids (Figure 1) which is explained in Table 1. The learning path is based on educational theories and teaching approaches [3] that are focused on developing knowledge at all levels, especially developing problem-solving knowledge, including visualisation and critical thinking.

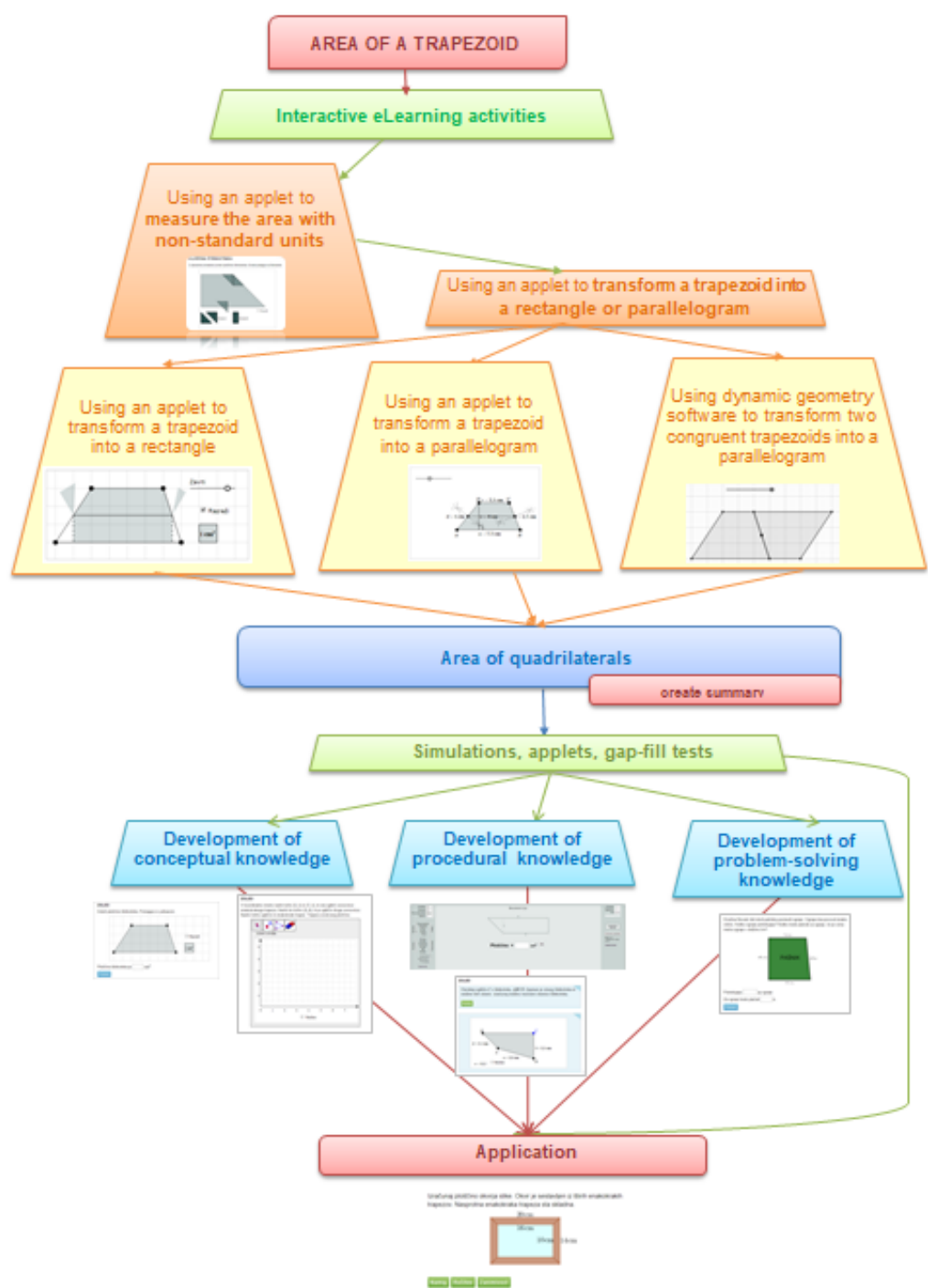

Fig. 1. The learning path 
Table 1. The learning path: Area of a trapezoid

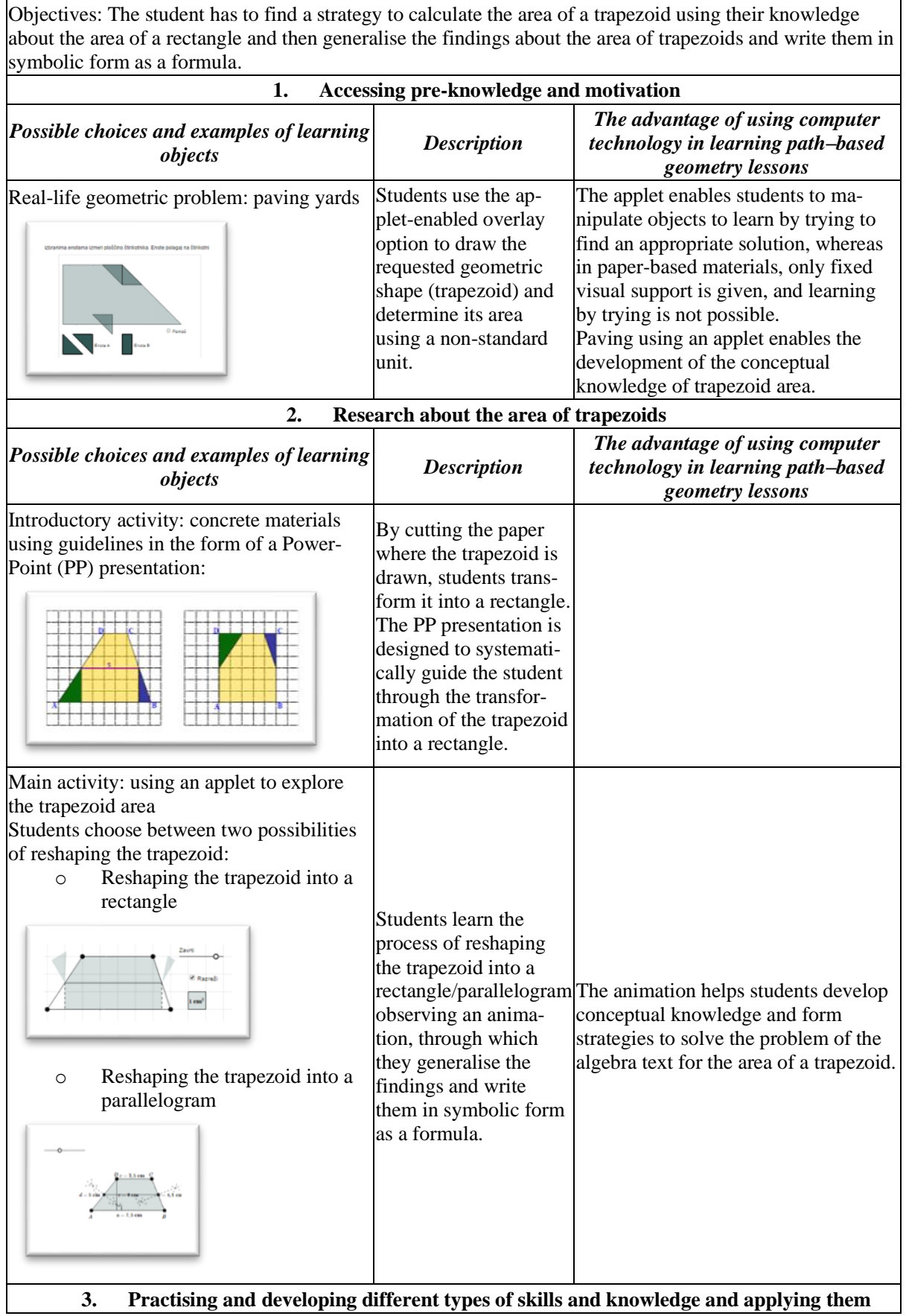




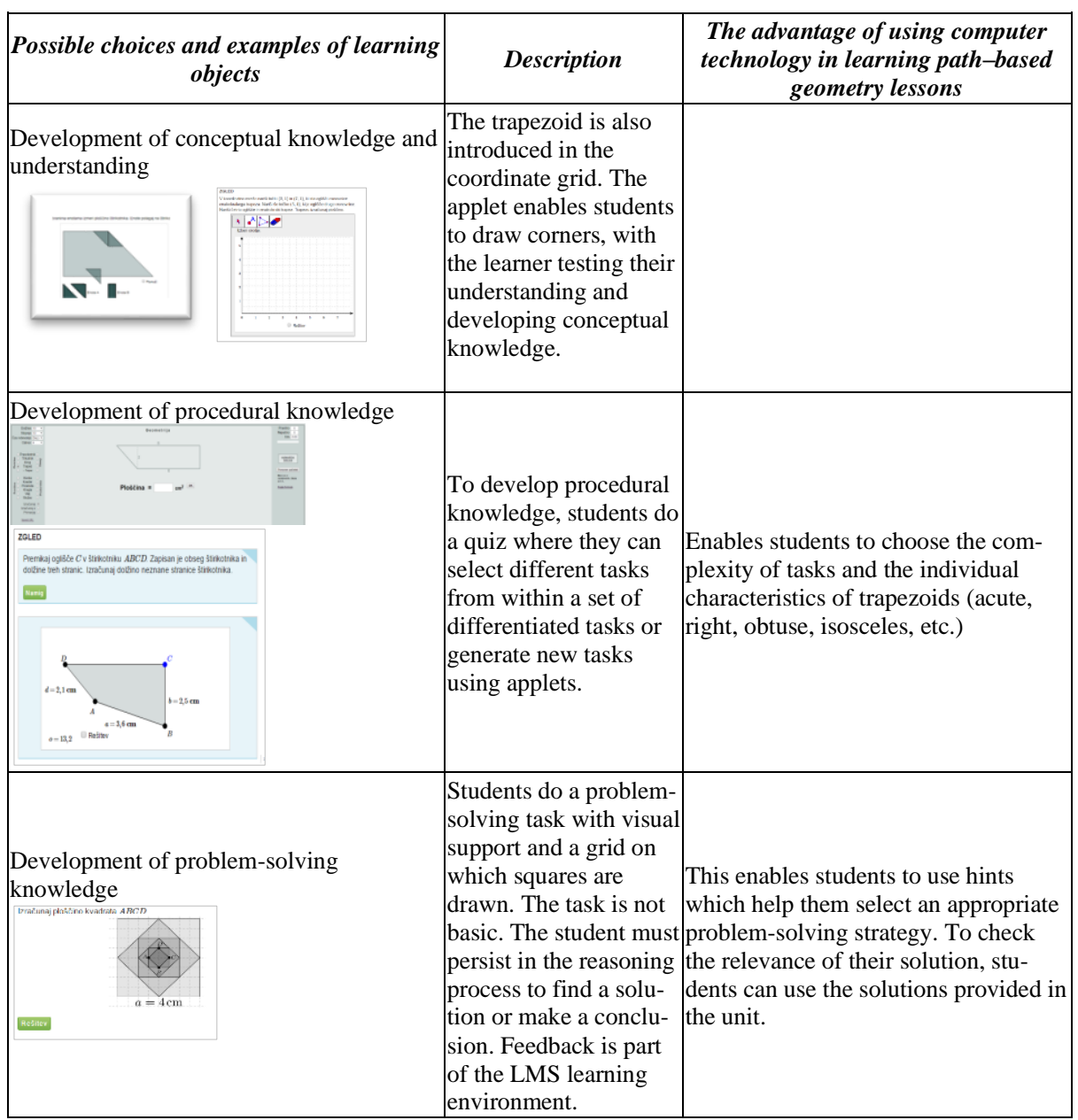

\section{Purpose of The Study}

Due to the advantages of using technology in teaching and learning [27] and the insufficient use of ICT in mathematics education and pedagogical approaches that develop students' spatial-visualisation abilities [7], [11] we developed a model of pathbased geometry learning in an LMS-based learning environment.

Based on Gagné's intellectual skills involved in problem solving [8], we considered three levels of math knowledge: conceptual knowledge, procedural knowledge and problem-solving knowledge [23].

The purpose of the study was to develop a model of path-based geometry learning in seventh grade and examining whether path-based learning environment can be more effective than conventional instruction for different levels of knowledge (adapted version of Gagné's taxonomy): 
- Taxonomy level I - conceptual knowledge - knowing and understanding basic geometric concepts and facts

- Taxonomy level II - procedural knowledge

- Taxonomy level III - problem-solving knowledge - solving simple and complex (geometric) problems

\subsection{Research question and research hypotheses}

The research was conducted among seventh-graders using a model of path-based geometry learning to enable higher-order learning outcomes. By teaching seventhgrade geometry in an LMS learning environment, we examined how students' conceptual, procedural and problem-solving knowledge was supported to answer the following research question:

Can be path-based geometry learning (experimental group) more effective than conventional instruction (control group) for different levels of knowledge?

General hypotheses: Seventh-grade students who have a model of path-based geometry learning will be more successful in solving geometric tasks than students who receive traditional, discrete maths lessons.

H1. The experimental group (EG) will be more successful than the control group (CG) on the level of basic, conceptual knowledge (first level).

H2. The EG will be more successful than the CG in solving tasks on the level of procedural knowledge (second level).

H3. The EG will be more successful than the CG in solving tasks on the level of problem-solving knowledge (third level).

H4. The EG will be more successful than the CG in overall score.

When testing hypotheses, we used a significance level of 0.05 .

\section{$5 \quad$ Methodology}

A causal, descriptive experimental method of pedagogical research was used to validate the hypotheses. The group of students who received the experimental factor formed the EG, and the group of students who did not receive the experimental factor formed the $\mathrm{CG}$.

Data were collected quantitatively by pre- and post-participation tests.

The effectiveness of the path-based geometry learning model was tested using a one-factor pedagogical experiment with classes as comparison groups. The experimental factor had two modalities: geometry lessons based on the path-based geometry learning model (EG) and geometry lessons based on the transmission approach with traditional aids (CG).

\subsection{Description of the lesson model in the control group}

The CG followed the same learning objectives and content as the EG. The geometry lesson in the CG was based on transmission, a teacher-centred approach in which the teacher is the dispenser of knowledge and the final evaluator of learning. Teachers first explained the content in lectures, which was followed by students solving tasks 
on all three levels of knowledge. Students also received homework, where similar tasks had to be solved. In geometry lessons, students in the CG used geometric tools, textbooks and notebooks. In the textbooks, the instructions for most tasks which applied to calculating the perimeters and areas of triangles and quadrilaterals did not include visual support. The tasks more often focused on the development of procedural knowledge.

\subsection{Description of the lesson model in the experimental group}

We designed and evaluated a model of path-based learning of seventh-grade geometry in an LMS-based learning environment (the model is described in Section 3). For the EG, the learning path was designed in the LMS by applying a range of learning objects including use of dynamic geometry programs and applets. Individualised learning in the model of path-based geometry learning was supported by a teacher and by guidelines. The EG developed knowledge on all three levels through research. The path-based approach facilitates self-directedness and the autonomous selection of learning objects.

\subsection{Experiment sample}

The study included 125 seventh-grade students randomly selected from three Slovenian schools. Sixty-three students from all three schools were included in the EG, and 62 from all three schools were included in the CG. The EG consisted of 31 boys and 32 girls, while the CG had 38 boys and 24 girls. A total of 69 boys and 56 girls participated in the study. Six maths teachers participated, all with the same level of education - university degrees and at least 10 years of work experience. All the schools were provided with adequate ICT.

\section{$5.4 \quad$ Variables}

The experimental factor is the independent variable. The data, collected with preand post-participation tests, represent the dependent variables in the statistical context. For all students who took part in the study, we obtained data on gender (male and female), the class they attended, their final grades in mathematics and Slovenian, and their average final grades, which represent in the statistical context the control variables.

\subsection{Data collection}

We collected data with pre- and post-participation tests, which classified tasks according to a three-level taxonomy of conceptual, procedural and problem-solving knowledge. We used a pre-participation test to establish the initial equivalence between EG in CG students in their knowledge of seventh-grade maths (Table 3). We conducted pre-participation testing before starting the experiment (first empirical recording) before the model of path-based geometry learning was integrated into the 
EG. The post-participation test (the second empirical recording) was conducted one week after the experiment under the same conditions and with the same tester.

The data, collected with pre- and post-participation tests, represent the dependent variables in the statistical context.

The data presented in the statistical context by dependent variables were provided to us by the class teacher and the mathematics teacher of the students involved in the survey. Consent from the parents for the students' participation in the research was obtained beforehand.

Validity, reliability and objectivity: We designed the pre-participation test to examine the equivalence between the EG and CG and post-participation tests for the purpose of this experiment after discussing the content of both tests and the applicability of the three-level taxonomy to learning outcomes. We used Cronbach's alpha coefficient to calculate the reliability of both tests, both of which were higher than 0.8 , indicating acceptable levels of reliability. We verified the validity of the tests by a factor analysis, which demonstrated that the first factor in the pre-participation test accounted for $25.3 \%$ of the variance, whereas the first factor in the post-participation test accounted for $25.7 \%$ of the variance, meaning that the tests had construct validity. We ensured the objectivity of the pre- and post-participation tests during both testing and evaluation by conducting the evaluation according to previously established criteria uniformly for all the tested students in both groups. The data collection was performed according to the same procedure for both groups as well.

Difficulty and discrimination: Difficulty index is defined as the percentage of those students who gave the correct response for a particular task.

The difficulty index (IT) was calculated according to the formula:

$$
I T=\frac{\bar{t}_{j}}{\bar{t}_{j_{\max }}}
$$

where $\bar{t}_{j}$ represents the average number of points for task $\mathrm{j}$, and $\bar{t}_{j_{\text {max }}}$ represents the maximum possible number of points for task $\mathrm{j}$.

The difficulty index of most tasks was within an acceptable range from 31.6$84.4 \%$.

The index of discrimination (ID) showed that most tasks had acceptable values (ID $>20 \%$ ). Twenty-two subtasks had IDs above $40 \%$, which shows a good discrimination of tasks; five subtasks had IDs between $20 \%$ and $40 \%$, which indicates medium discrimination; and one subtask had an ID under $20 \%$, which indicates poor discrimination. The average ID value was $54 \%$.

\subsection{Statistical processing}

We used the Statistical Package for the Social Sciences (SPSS) 22 to process the quantitative data.

The pre-participation test established the initial equivalence between EG and CG students. We used a t-test to determine the significance of the difference between the EG and CG in the pre-participation tests for individual taxonomy levels (according to the adapted version of three-level taxonomy of conceptual, procedural and problem- 
solving knowledge), and overall score. The EG and the CG were equal in the preparticipation test on different levels of knowledge and in overall score.

We also used a t-test to determine the significance of the difference between the EG and the CG in the post-participation test on all levels of knowledge.

\subsection{Results and discussion}

The results were interpreted in accordance with the proven hypotheses. In doing so, we considered the maximum allowable risk of rejection of a hypothesis to be $5 \%$ (a significance level of 0.05). If the level of statistical significance in the t-test was lower than 0.05 , this meant that the EG and CG were statistically significantly different based on the tested hypothesis.

Results of pre-test: In pre-test we analyzed the differences in the knowledge of geometry between the students in the experimental group and the ones in the control group in the initial phase based on taxonomy levels and overall score on the pre-test.

The purpose of the pre-test was to test pre-knowledge in geometry acquired by the students in the first and second three-year education periods.

In the initial phase, we tested the students' knowledge of geometry at different taxonomy levels: understanding basic geometric concepts and facts (taxonomy level I), using procedural knowledge (taxonomy level II), problem-solving knowledge (taxonomy level III).

Table 2 shows the basic statistical parameters of the pre-test: the number of students in the EG and CG, the arithmetic mean, the standard deviation, the standard mean error and the lowest and highest scores for different taxonomy levels and overall score.

Table 2. Pre-test scores - basic statistical parameters for achievement (in \%) for individual taxonomy levels and overall score by group (EG, CG)

\begin{tabular}{|c|c|c|c|c|c|c|c|}
\hline Variable & Group & $\mathbf{N}$ & $\mathbf{M}$ & SD & SE & Min & Max \\
\hline \multirow{2}{*}{$\begin{array}{l}\text { Taxonomy level I (conceptual } \\
\text { knowledge) }(\%)\end{array}$} & EG & 63 & 54.1 & 19.9 & 2.5 & 22.2 & 100.0 \\
\hline & $\mathrm{CG}$ & 62 & 47.8 & 22.4 & 2.8 & 11.1 & 100.0 \\
\hline \multirow{2}{*}{$\begin{array}{l}\text { Taxonomy level II (procedural } \\
\text { knowledge) }(\%)\end{array}$} & EG & 63 & 53.3 & 21.9 & 2.8 & 8.3 & 100.0 \\
\hline & $\mathrm{CG}$ & 62 & 50.0 & 21.9 & 2.8 & 8.3 & 100.0 \\
\hline \multirow{2}{*}{$\begin{array}{l}\text { Taxonomy level III (problem-solving } \\
\text { knowledge) }(\%)\end{array}$} & EG & 63 & 37.6 & 25.2 & 3.2 & 0.0 & 100.0 \\
\hline & $\mathrm{CG}$ & 62 & 35.7 & 27.4 & 3.5 & 0.0 & 100.0 \\
\hline \multirow{2}{*}{ Overall score $(\%)$} & EG & 63 & 48.8 & 19.2 & 2.4 & 10.0 & 100.0 \\
\hline & $\mathrm{CG}$ & 62 & 45.1 & 20.7 & 2.6 & 10.0 & 93.3 \\
\hline
\end{tabular}

EG - experimental group, $\mathrm{CG}$ - control group, $\mathrm{N}$ - number of students, $\mathrm{M}$ - mean, $\mathrm{SD}$ - standard deviation, SE - standard error of a mean, Min - minimum, Max - maximum

The students in the EG achieved the highest results in tasks on level I (54.1\%), but they had the lowest results in tasks on taxonomy level III (37.6\%).

The students in the CG achieved the highest results in tasks on taxonomy level II (50\%), but they had the lowest results in tasks on taxonomy level III (35.7\%).

The results show that the students in the EG were more successful in the pre-test on all three taxonomy levels than the students in the CG (both in the knowledge and 
understanding of basic geometric concepts, the use of procedural knowledge, and problem-solving knowledge). Furthermore, also in overall score achieved on the pretest students in the EG were more successful $(48.8 \%)$ than the students in the CG $(45.1 \%)$.

A t-test (Table 3) was used to check and confirm that there were no statistically significant differences in the pre-test between the EG and CG in the achievements on different taxonomy levels and in overall score $(\mathrm{p}>0.05)$.

Table 3. Pre-test scores - t-test for independent samples to verify the differences between the EG and CG in achievement on individual taxonomy levels and overall score

\begin{tabular}{|l|c|c|c|c|c|}
\hline \multicolumn{1}{|c|}{ Variable } & $\mathbf{t}$ & $\mathbf{d f}$ & $\mathbf{p}$ & $\begin{array}{c}\text { Mean } \\
\text { Difference }\end{array}$ & SE Difference \\
\hline Taxonomy level I (conceptual knowledge) (\%) & 1.663 & 123 & 0.099 & 0.063 & 0.038 \\
\hline Taxonomy level II (procedural knowledge) (\%) & 0.844 & 123 & 0.400 & 0.033 & 0.039 \\
\hline Taxonomy level III (problem-solving knowledge) (\%) & 0.404 & 123 & 0.687 & 0.019 & 0.047 \\
\hline Overall score (\%) & 1.060 & 123 & 0.291 & 0.038 & 0.036 \\
\hline $\begin{array}{l}\text { t - value of the t-test for independent samples, df - degrees of freedom, p - level of statistical significance } \\
\text { (2-tailed) }\end{array}$
\end{tabular}

Results of post-test: In post-test we analyzed the differences in the knowledge of geometry between the students in the EG and the ones in the CG in the final phase based on taxonomy levels and the overall score in the post-test.

Table 4 shows the basic statistical parameters of the post-test: the number of students in the EG and CG, the arithmetic mean, the standard deviation, the standard mean error, and the lowest and highest scores for different taxonomy levels and overall score.

Table 4. Post-test scores - basic statistical parameters for achievement (in \%) for individual taxonomy levels and overall score by group (EG, CG)

\begin{tabular}{|l|c|c|c|c|c|c|c|}
\hline \multicolumn{1}{|c|}{ Variable } & Group & N & M & SD & SE & Min & Max \\
\hline \multirow{2}{*}{$\begin{array}{l}\text { Taxonomy level I (conceptual } \\
\text { knowledge) (\%) }\end{array}$} & EG & 63 & 67.9 & 23.9 & 3.0 & 0.0 & 100.0 \\
\cline { 2 - 8 } & CG & 62 & 59.5 & 26.9 & 3.4 & 0.0 & 100.0 \\
\hline $\begin{array}{l}\text { Taxonomy level II (procedural } \\
\text { knowledge) (\%) }\end{array}$ & EG & 63 & 59.3 & 29.0 & 3.7 & 0.0 & 100.0 \\
\cline { 2 - 8 } $\begin{array}{l}\text { Taxonomy level III (problem-solving } \\
\text { knowledge) (\%) }\end{array}$ & EG & 62 & 52.3 & 26.7 & 3.4 & 8.3 & 100.0 \\
\cline { 2 - 8 } & CG & 62 & 20.3 & 22.7 & 2.9 & 0.0 & 100.0 \\
\hline \multirow{2}{*}{ Overall score (\%) } & EG & 63 & 52.9 & 22.6 & 2.8 & 3.3 & 100.0 \\
\cline { 2 - 8 } & CG & 62 & 44.8 & 22.2 & 2.8 & 3.3 & 100.0 \\
\hline
\end{tabular}

EG - experimental group, $\mathrm{CG}$ - control group, $\mathrm{N}$ - number of students, $\mathrm{M}$ - mean, $\mathrm{SD}$ - standard deviation, $\mathrm{SE}$ - standard error of a mean, Min - minimum, Max - maximum

In the post-test, students in the EG achieved the highest results in tasks on taxonomy level I (67.9\%). The lowest results they achieved in tasks on taxonomy level III $(29.5 \%)$. 
The students in the $\mathrm{CG}$ also achieved the highest results in tasks on taxonomy level I (59.5\%), while also achieving the lowest results in tasks on taxonomy level III $(20.3 \%)$.

The results show that the students in the EG were more successful in the post-test on all three taxonomy levels than the students in the CG (in the knowledge and understanding of basic geometric concepts, the use of procedural knowledge and problemsolving knowledge) and in the overall score achieved. The students in the EG achieved an average of $52.9 \%$ of all points, whereas the students in the CG scored an average of $44.8 \%$ of all points.

We further examined whether these differences were statistically significant.

As in the initial phase - before the introduction of the experimental factor - to determine whether the EG and CG were even in terms of individual taxonomy levels and the overall score, we used a t-test (Table 5) to check the statistical significance of the differences between group achievements.

Table 5. Table 5: Post-test scores - t-test for independent samples to verify the differences between the EG and CG in the achievement on individual taxonomy levels and overall score

\begin{tabular}{|l|c|c|c|c|c|c|}
\hline \multicolumn{1}{|c|}{ Variable } & $\mathbf{t}$ & $\mathbf{d f}$ & $\mathbf{p}$ & Mean Difference & $\begin{array}{c}\text { SE } \\
\text { Difference }\end{array}$ & $\begin{array}{c}\text { Cohen } \\
\mathbf{d}\end{array}$ \\
\hline Taxonomy level I (conceptual knowledge) (\%) & 1.847 & 123 & 0.067 & 0.084 & 0.045 & 0.33 \\
\hline $\begin{array}{l}\text { Taxonomy level II (procedural knowledge) } \\
(\%)\end{array}$ & 1.397 & 123 & 0.165 & 0.070 & 0.050 & 0.25 \\
\hline $\begin{array}{l}\text { Taxonomy level III (problem-solving } \\
\text { knowledge) (\%) }\end{array}$ & 2.195 & 123 & 0.030 & 0.092 & 0.042 & 0.39 \\
\hline $\begin{array}{l}\text { Overall score (\%) } \\
\text { t - value of the t-test for independent samples, df - degrees of freedom, p - level of } \\
\text { statistical significance (2-tailed) }\end{array}$ & & & \\
\hline
\end{tabular}

We analysed the differences in the knowledge and understanding of basic geometric concepts between students from the experimental and the control groups in the final phase.

In the initial phase, students in the EG achieved slightly better average results $(54.1 \%)$ in tasks on taxonomy level I (knowledge and understanding of basic geometric concepts) than the students in the CG $(47.8 \%)$, but these differences were not statistically significant.

In comparing the arithmetic means of the achievements of the EG and CG on taxonomy level I (knowledge and understanding of basic geometric concepts), the EG was also more successful $(67.9 \%)$ than the CG $(59.5 \%)$ on the post-test. The difference between the arithmetic means increased from $6.3 \%$ to $8.4 \%$ (Table 2 and Table 4 , respectively).

Despite a slightly higher achievement of the students in the EG than the CG in the knowledge and understanding of basic geometric concepts, the t-test showed that the differences were not statistically significant $(\mathrm{t}(123)=1.847, \mathrm{p}=0.064)($ Table 5$)$. 
The calculated arithmetic means, the results of the t-test and the level of statistical significance indicate that the EG and CG were equal in the post-test in the knowledge and understanding of basic geometric concepts, as there were no statistically significant differences between the achievements of the experimental and the control groups. The first hypothesis is therefore rejected.

The tasks of taxonomy level I checked the students' knowledge and understanding of basic geometric concepts, geometric shapes and their properties, the names of shapes, and reading data from images to be used when performing procedures and drawing shapes.

We expected the students in the EG to have more knowledge of basic geometric concepts than the students in the CG based on the assumption that the knowledge obtained through an active learning process is higher-quality. In addition, we attributed great importance to (1) visualising geometric concepts while using dynamic geometry programs and applets and (2) ongoing feedback and its impact on the construction of concepts or changing conceptual representations. The students in the EG achieved a higher average result in the post-test than the students in the CG, but the differences between the two groups were not statistically significant. The students in the CG had lessons in the traditional model, where the teacher first explained the geometric concepts to the students, which was followed by consolidation and repetition by solving different tasks, enabling the students to memorise the concepts. In the EG, students independently explored the content on the perimeters and areas of triangles and quadrilaterals in an LMS-based learning environment, using dynamic geometry programs, applets and other interactive material. The material was supported by various visual elements that helped students construct and understand conceptual representations. Most students required more time when exploring content independently, which means they solved fewer tasks in the consolidation phase compared to the students in the CG.

Based on the results, the learning approach in the EG better enables students to successfully obtain knowledge and understand basic geometric concepts.

We analysed the differences in the use of procedural knowledge between students from the experimental and the control groups in the final phase.

In the initial phase, students in the EG also achieved a slightly better average result $(53.3 \%)$ in tasks on taxonomy level II (use of procedural knowledge) than the students in the CG $(50 \%)$, but these differences were not statistically significant.

If comparing the arithmetic means of the achievements of the EG and CG on taxonomy level II (use of procedural knowledge), we can see that the EG was also more successful $(59.3 \%)$ than the CG $(52.3 \%)$ in the post-test. The difference between the arithmetic means increased from 3.3\% to 7\% (Table 2 and Table 4, respectively).

Despite the slightly higher achievement of the students in the EG than the CG in the use of procedural knowledge, the t-test showed that the differences were not statistically significant $(\mathrm{t}(123)=1.397, \mathrm{p}=0.165)$ (Table 5). The calculated arithmetic means, the results of the t-test and the level of statistical significance indicate that the EG and CG were even in the post-test in the use of procedural knowledge, as there were no statistically significant differences between the achievements of the EG and CG. The second specific hypothesis was therefore rejected as well. 
In the post-test, tasks on taxonomy level II checked the use of simple and advanced procedural knowledge by means of direct and indirect tasks. Students calculated the perimeters and areas of triangles and quadrilaterals, calculated the lengths of sides based on the given data, and used them to calculate the perimeter and area of the given shape and drew shapes (also in the coordinate grid).

The aim of the study was to check whether a suitable approach could help students successfully solve tasks on taxonomy level II (use of procedural knowledge), as the applied model of path-based geometry learning lacked an emphasis on systematic solving and recording procedures, unlike the traditional lessons given to the CG. Traditional instruction attributes great importance to procedural knowledge, so plenty of time is dedicated to practising routine, complex procedures, often without knowing or understanding the basic geometric concepts, which is a precondition for complex procedures. CG students thus solved many tasks that helped them practise routine, complex procedures, while in the EG, students acquired procedural knowledge from didactic games and quizzes, where they could master both simple and complex procedures with adequate visual support (visual material and animations). Students in the EG were more successful in using procedural knowledge than those students in the CG, but these differences were not statistically significant.

As already mentioned, the pre-condition for a successful execution of complex procedures is knowing and understanding of concepts, which was also shown by the results. Compared to the $\mathrm{CG}$, the EG achieved a better average result in both the knowledge and understanding of basic geometric concepts as well as in the use of procedural knowledge.

We analysed the differences in solving simple and complex problems (problemsolving knowledge) between students from the experimental and control groups in the final phase.

In the initial phase, students in the EG achieved a slightly better average result $(37.6 \%)$ in tasks on taxonomy level III (solving simple and complex problems) than the students in the CG (35.7\%), but these differences were not statistically significant.

If comparing the arithmetic means of the achievements of the EG and CG on taxonomy level III (solving simple and complex problems), we can see that the EG was also more successful $(29.5 \%)$ than the CG $(20.3 \%)$ on the post-test. The difference between the arithmetic means increased from $1.9 \%$ to $9.2 \%$ (Table 2 and Table 4, respectively).

As the EG and CG were even in terms of student achievements on taxonomy level III, we used a t-test to check whether the differences between the groups were statistically significant.

The calculated arithmetic means, the t-test results $(\mathrm{t}(123)=2.195, \mathrm{p}=0.030)$ and the level of statistical significance (Table 5) indicate that the differences in the achievements of the students from the EG and CG in solving simple and complex problems were statistically significant in favour of the EG. This confirms our third hypothesis.

In tasks on taxonomy level III, students were required to identify the relevant shapes and their sides on a sketch, use the given visual support to transform the text (including algebraic text) of the problem into mathematical language, read the rele- 
vant data from the sketch and create an appropriate strategy to solve the problem using the acquired data.

The goals of the curriculum, national and international strategies and national student assessment and international research, such as Trends in International Mathematics and Science Study (TIMSS) and PISA, are also to build students' knowledge to successfully solve mathematical problems and real-life problems. Students build problem-solving knowledge through different problem situations that are new to them, cannot be predicted and are therefore unexpected, which promotes the development of mathematical thinking: creative, critical, analytical, systemic thinking. For this purpose, we designed a model of path-based geometry learning in an LMS-based learning environment with the use of dynamic geometry programs and applets based on a process/didactic approach.

We analysed the differences between students from the experimental and the control groups in the final phase based on the total number of points.

In the initial phase, students in the EG achieved a slightly better average result (48.8\%) based on the total number of points than the students in the CG (45.1\%), but these differences were not statistically significant $(\mathrm{t}(123)=1.060, \mathrm{p}=0.291)$ (Table 3).

In comparing the arithmetic means of the achievements of the EG and CG based on the total number of points, the EG was also more successful $(52.9 \%)$ than the CG $(44.8 \%)$ in the post-test. The difference between the arithmetic means increased from $3.8 \%$ (Table 3) to $8.1 \%$ (Table 5), which means that the average result of the post-test was $8.1 \%$ better in the EG.

As the EG and CG were even in terms of student achievements based on the overall score, a t-test was used to check whether the differences between the groups were statistically significant.

The calculated arithmetic means, the t-test results $(\mathrm{t}(123)=2.015, \mathrm{p}=0.046)$ and the level of statistical significance (Table 5) indicated that the differences in the achievements of the students from the experimental and control groups in the total number of points were statistically significant in favour of the EG. This confirms our fourth specific hypothesis.

The t-test showed that the statistically significant differences in the post-test were in favour of the EG on taxonomy level III $(\mathrm{t}(123)=2.195, \mathrm{p}=0.030)$ and the overall score $(\mathrm{t}(123)=2.015, \mathrm{p}=0.046)$. There was medium effect size for problem-solving knowledge (taxonomy level III) $(r=0.39)$ and for the overall score $(r=0.36)$. On average, the result of the EG in the post-test was $8.1 \%$ better (Table 5). This answers on our general research hypothesis: Seventh-grade students who had the model of path-based geometry learning were more successful in solving geometric tasks than the students that receive traditional, discrete maths lessons.

\section{Conclusion}

The model of path-based geometry learning in the LMS-based learning environment with the use of dynamic geometry programs and applets, which was based on a 
cognitive/constructivist method of teaching, was implemented in teaching practice to check its effects on learning achievements.

The analysis of the results showed that the students who had the model of pathbased geometry learning achieved higher scores at all levels of knowledge, and the EG achieved statistically significantly better results with a medium-size effect on solving simple and complex problems, and the overall score. The results show that path-based geometry learning empirically develops knowledge at higher cognitive levels.

This model gives students the option to choose, as the online learning environment enables them to encounter various physical and virtual situations. Students thus (co)create their learning paths and have the opportunities to make less linear, hierarchical, systematic progress. The online learning environment with the use of dynamic geometry programs and applets allowed students to observe different representations and transitions between them, which has a significant impact on the development of the ability to visualise. Students built geometric representations on a concrete level, followed by a transition to a symbolic level supported by visual aids, and the use of animations allowed students to initiate and observe the process and repeat it if needed. Impersonal, impartial, real-time feedback also played an important role. Activities were directed towards solving and researching different geometric problems. Problem-solving develops divergent and convergent thinking, creativity, argumentation and decision-making abilities, and the ability to make interdisciplinary connections.

A study on learning and teaching basic geometric concepts in elementary school [11] also found that the use of several means in the formulation of geometric concepts had a positive effect on student achievements in geometry. We found similar arguments in the baseline of the TIMSS 2011 [12] and PISA 2012 studies [21], which emphasised that the last education period should focus on visualising basic geometric concepts, as this is the only way for students to use spatial representations to transition between three-dimensional and two-dimensional shapes and their visualisations.

Raphael and Wahlstrom [18] and Fuys et al. [8] also found that the use of didactic aids was crucial for a successful visualisation of geometric concepts. The aids that allow both visualisation and manipulation simultaneously facilitate the construction of basic geometric concepts and enable suitable cognitive visualisation.

\section{$7 \quad$ Acknowledgement}

The article was written as part of project activities of national project NA-MA POTI - Natural Science and Mathematical Literacy: Promoting Critical Thinking and Problem Solving and efficient use of ICT. Investment is co-financed by the Republic of Slovenia and the European Union under the European Social Fund. Under the Operation programme for the Implementation of the European Cohesion Policy in the 2016-2022 period.

Research by Andreja Istenič Starčič was financially supported by the Slovenian Research Agency (P2-0210). 


\section{$8 \quad$ References}

[1] J. Bruner, Toward a theory of instruction. Cambridge: The Belknap Press of Harvard University Press, 1966.

[2] C. M. Chen, "Intelligent web-based learning system with personalized learning path guidance," Computers \& Education, vol. 51, no. 2, pp. 787-814, 2008. https://doi.org/10. 1016/j. compedu.2007.08.004

[3] T. Anderson Ed., The Theory and Practice of Online Learning, 2nd ed., Edmonton: Athabasca University, 2008.

[4] C. De Smet, T. Schellens, B. De Wever, P. Brandt-Pomares, and M. Valcke, "The design and implementation of learning paths in a learning management system," Interactive Learning Environments, vol. 24, no. 6, pp. 1076-1096, 2014. https://doi.org/10.1080/104 $\underline{94820.2014 .951059}$

[5] C. De Smet, B. De Wever, T. Schellens, and M. Valcke, "Differential impact of learning path-based versus conventional instruction in science education," Computers \& Education, vol. 99, pp. 53-67, 2016. https://doi.org/10.1016/j.compedu.2016.04.001

[6] Eurydice, Key data on learning and innovation through ICT at school in Europe 2011. Brussels: Education, Audiovisual and Culture Executive Agency, 2011.

[7] Eurydice, Mathematics education in Europe: common challenges and national policies. Brussels: Education, Audiovisual and Culture Executive Agency, 2011.

[8] D. Fuys, D. Geddes, and R. Tischler, "The Van Hiele model of thinking in geometry among adolescents," Journal for Research in Mathematics Education. Monograph, vol. 3, pp. i-196, 1988. https://doi.org/10.2307/749957

[9] R. M. Gagné, and L. J. Briggs, Principles of instructional design. New York: Holt, Rinehart \& Winston, 1974.

[10] M. Hohenwarter, D. Jarvis, and Z. Lavicza, "Linking geometry, algebra and mathematics teachers: GeoGebra software and the establishment of the International GeoGebra Institute," International Journal for Technology in Mathematics Education, vol. 16 no. 2, pp. 83-87, 2009.

[11] S. Mešinović, M. Cotič, and A. Žakelj, "Učenje in poučevanje osnovnih geometrijskih pojmov," Pedagoška Obzorja: Časopis za Didaktiko in Metodiko, vol. 32, no. 2, pp. 49-66, 2017.Available:https://www.dlib.si/details/URN:NBN:SI:DOC-04OK9GFM. https://doi.org/10.26493/978-961-7055-61-0

[12] I. V. Mullis, M. Martin, P. Foy, and A. Arora, TIMSS 2011 International Results in Mathematics. Boston: TIMSS \& PIRLS International Study Center, 2012.

[13] National Examinations Centre/Republiški izpitni center, Nacionalno preverjanje znanja. Letno poročilo o izvedbi nacionalnega preverjanja znanja v šolskem letu 2010/2011 (National Assessment of Knowledge - Annual Report 2010/2011). Ljubljana: Državni izpitni center,2011.Available:http://www.ric.si/mma/letno\%20poro\%C4\%8Dilo\% 20npz\%202011/2011121413073859/. [Accessed, Jul 22, 2018].

[14] National Examinations Centre/Republiški izpitni center, Nacionalno preverjanje znanja. Letno poročilo o izvedbi nacionalnega preverjanja znanja v šolskem letu 2011/2012 (National Assessment of Knowledge - Annual Report 2011/2012). Ljubljana: Državni izpitni center, 2012. Available: http://www.ric.si/mma/Letno\%20porocilo\%20NPZ\%202012/ 2012112814020529/. [Accessed, Jul 22, 2018]. 
[15] National Examinations Centre/Republiški izpitni center, Nacionalno preverjanje znanja. Letno poročilo o izvedbi nacionalnega preverjanja znanja v šolskem letu 2012/2013 (National Assessment of Knowledge - Annual Report 2012/2013). Ljubljana: Državni izpitni center, 2013. Available: http://www.ric.si/mma/Letno\%20porocilo\%20NPZ\%202013/ 2013101507274770/. [Accessed, Jul 22, 2018].

[16] National Examinations Centre/Republiški izpitni center, Nacionalno preverjanje znanja. Letno poročilo o izvedbi nacionalnega preverjanja znanja v šolskem letu 2013/2014 (National Assessment of Knowledge - Annual Report 2013/2014). Ljubljana: Državni izpitni center, 2014. Available: http://www.ric.si/mma/Letno\%20porocilo\%20NPZ\%202014\%20 dokoncno\%202/2014121113504097/. [Accessed, Jul 22, 2018].

[17] National Examinations Centre/Republiški izpitni center, Nacionalno preverjanje znanja. Letno poročilo o izvedbi nacionalnega preverjanja znanja v šolskem letu 2014/2015 (National Assessment of Knowledge - Annual Report 2014/2015). Ljubljana: Državni izpitni center, 2015. Available: http://www.ric.si/mma/Letno\%20porocilo\%20NPZ\%202015/2015 121606591578/. [Accessed, Jul 22, 2018].

[18] D. Raphael, and M. Wahlstrom, "The influence of instructional aids on mathematics achievement;" Journal for Research in Mathematics Education, vol. 20, no. 2, pp. 173-190, 1989. https://doi.org/105951/jresematheduc.20.2.0173

[19] N. R. Sanchez, C. Mayapadrón, I. Martínez-Salazar, and F. Torres-Guerrero, "Design and evaluation of planning and mathematical models for generating learning paths," Computational Intelligence, vol. 34, no. 3, pp. 821-838, 2018. https://doi.org/10.1111/coin. $\underline{12134}$

[20] M. Štraus, M. Repež, and S. Štigl, "Nacionalno poročilo o raziskavi PISA 2006/Pisa 2006 National Report,” Pedagoški Inštitut/Educational Research Institute, 2007. Available: https://www.pei.si/wp-content/uploads/2018/12/PISA2006NacionalnoPorocilo.pdf.

[21] M. Štraus, K. Šterman Ivančič, and S. Štigl, “OECD PISA 2012,” Pedagoški Inštitut/Educational Research Institute, 2012. [Online]. Available: https://www.pei.si/ wp-content/uploads/2018/12/PISA-2012-Povzetek-rezultatov-SLO.pdf.

[22] F. Yang, F. W. B. Li, and R. W. H. Lau, "An open model for learning path construction," in Advances in web-based learning - ICWL 2010. Lecture notes in computer science, X. Luo, M. Spaniol, L. Wang, Q. Li, W. Nejdl, and W. Zhang, Eds. Berlin, Heidelberg: Springer, 2010, pp-318-328. https://doi.org/10.1007/978-3-642-17407-0_33

[23] ] M. Volk., M. Cotič, M. Zajc, and A. Istenic, Starcic, "Tablet-based cross-curricular maths vs. traditional maths classroom practice for higher-order learning outcomes," Computers \& Education, vol. 114, pp. 1-23, 2017. https://doi.org/10.1016 /j.compedu.2017.06.004

[24] . A. Wiley, "Learning objects explained," in The instructional use of learning objects, D. A. Wiley, Ed. Bloomington: Agency for Instructional Technology and Association for Educational Communications \& Technology, 2002, pp-1-25.

[25] Z. Liu, L. Dong, and C. Wu, "Research on Personalized Recommendations for Students' Learning Paths Based on Big Data," International journal: emerging technologies in learning, vol. 15, no. 8 pp. 40-56, 2020. https://doi.org/10.3991/ijet.v15i08.12245

[26] Ministry of Education and Sport \& National Educational Institute / Ministrstvo RS za šolstvo in šport \& Zavod RS za šolstvo, "Program osnovna šola Matematika Učni načrt / Elementary school maths curriculum Slovenia," Ministry of Education and Sport \& Na- 
tional Educational Institute, 2011. [Online]. Available: https://www.gov.si/assets/ministrstva/MIZS/Dokumenti/Osnovna-sola/Ucninacrti/obvezni/UN_matematika.pdf. [Acessed, Jul 22, 2018].

[27] Š. Bagon, M. Gačnik, and A. Istenic Starcic, "Information communication technology use among students in inclusive classrooms," International journal: emerging technologies in learning, vol. 13, no. 6, pp. 56-72, 2018. https://doi.org/10.3991/ijet.v13i06.8051

[28] V. N. Galitskaya, and A. S. Drigas, "Special Education: Teaching Geometry with ICTs," International journal: emerging technologies in learning, vol. 15, no. 6, pp. 173-182, 2020. https://doi.org/10.3991/ijet.v15i06.11242

\section{Authors}

Andreja Klančar, $\mathrm{PhD}$, is teacher assistant and senior instructor of Educational technology at the Faculty of Education, University of Primorska in Koper, Slovenia. She is also math teacher at elementary school. Her field of research is the development and evaluation of different teaching approaches and the effective use of technology in the teaching and learning process. Email:andreja.klancar@pef.upr.s

Andreja Istenič Starčič, PhD, is professor in didactics at University of Primorska and University of Ljubljana, Slovenia. Her teaching and research interests include educational technology, teacher education, research evaluation, and particularly, interdisciplinary research. Andreja was editor of British Journal of Educational Technology and is member of editorial boards in Educational Technology Research and Development. Andreja has served as a visiting professor at the University of North Texas, Macquarie University Sydney, and Kazan Federal University. Andreja is author of the book Educational technology and construction of authentic learning environment. Email: andreja.starcic@pef.upr.si

Mara Cotič, $\mathrm{PhD}$, is an Associate Professor in Didactics of Mathematics and Elementary School Mathematics at the Faculty of Education Koper, University of Primorska. As a researcher in the area of didactic of mathematics develops new modern models of teaching and learning mathematics, above all in the area of data processing and problem knowledge. The results of her research work are besides scientific and professional articles and papers at the international meetings seen also in the didactic packages (handbooks for teachers, textbooks, exercises for consolidation) for all nine grades of primary schools as well as in two independent scientific monographies. In her articles and in her monography Data processing in the instruction of mathematics she demonstrated her model of data processing instruction in the first five grades of primary schools, which was a complete novelty in Slovenia. For the establishment of this model she took into consideration the results of her own empirical researches and the results of the researches of the most prominent scientists who deal with those questions, and she respected the specificity and characteristics of the Slovenian environment. In the monography Mathematical problems in the primary schools and in her scientific articles she demonstrated the model of teaching and learning, where the problems are the issuing point of all activities required to understand different mathematical contents and concepts. Her works represent a significant contribution to the 
theoretical issues and practical implementation of the development of Slovenian primary school didactics for mathematics. Email: mara.cotic@ pef.upr.si

Amalija Žakelj, $\mathrm{PhD}$, is professor in Didactics of Mathematics and Elementary School Mathematics at the Faculty of Education, University of Primorska. Her research is focused on the development of models of teaching and learning mathematics, involving problem situations and realistic problems as well as the complex questions about the meaning of mathematics education in connection with the effectiveness of teaching and learning. As leading expert of the area of didactics of mathematics she transfers her knowledge and experiences into the field of mathematics education. Her achievements in scientific, professional and pedagogical work in the field of mathematics didactics are useful both for students and teachers as well as for researchers in the field of pedagogical research. She is author of numerous scientific, professional and pedagogical articles, handbooks for teachers, textbooks and contributions at conferences in Slovenia and abroad. Email: amalija.zakelj@pef.upr.si

Article submitted 2021-01-20. Resubmitted 2021-02-25. Final acceptance 2021-02-26. Final version published as submitted by the authors. 